\title{
ANALISIS PEMASARAN SUSU SAPI DI KUD KARANGPLOSO DESA BOCEK KECAMATAN KARANGPLOSO KABUPATEN MALANG
}

\author{
WikaTrizulita, Dimas Pratidina Puri Astuti Hadiyani, Waluyo Edi Susanto \\ Fakultas Peternakan \\ Universitas Kanjuruhan Malang \\ Email:puriastuti@unikama.ac.id
}

\begin{abstract}
Abstrak
Tujuan penelitian ini adalah untuk mengetahui saluran pemasaran susu segar di KUD Karangploso Desa Bocek Kecamatan Karangploso Kabupaten Malang. Materi yang digunakan dalam penelitian ini adalah pemasaran susu sapi KUD Karangploso Desa Bocek Kecamatan Karangploso Kabupaten Malang. Metode yang digunakan dalam penelitian ini adalah metode survei dan wawancara langsung dengan anggota KUD Karangploso. Variabel penelitian meliputi biaya pemasaran, total keuntungan pemasaran, dan margin pemasaran. Hasil penelitian menunjukan bahwa saluran pemasaran susu sapi di Desa Bocek Kecamatan Karangploso Kabupaten Malang yaitu : Peternak $\rightarrow$ KUD $\rightarrow$ IPS $\rightarrow$ dan Konsumen. Biaya pemasaran Rp. 572,75 per liter, total keuntungan pemasaran Rp. 1.727,25 per liter dan margin pemasaran Rp. 2.300,00 per liter dan biaya pemasaran dari KUD ke konsumen total biaya pemasaran Rp 291,05 per liter, total keuntungan pemasaran Rp 2.808,96 per liter dan margin pemasaran Rp 3.100,00. Kesimpulan dari penelitian ini adalah bahwa saluran pemasaran susu sapi di KUD Karangploso Desa Bocek Kecamatan Karangploso Kabupaten Malang sudah lebih baik. Saran yang dapat peneliti berikan untuk peternak di Desa Bocek Kecamatan Karangploso Kabupaten Malang yakni harus lebih ditingkatkan lagi dalam beternak sapi perah supaya mendapatkan susu yang berkualitas baik.
\end{abstract}

Keyword: biaya, keuntungan, margin pemasaran, peternak

\section{MILK MARKETING ANALYSIS IN KUD KARANGPLOSOBOCEK VILLAGE KARANGPLOSO SUB-DISTRICT MALANG DISTRICT}

\begin{abstract}
The purpose of this study was to find out the marketing channels of fresh milk at Karangploso Village Cooperative in Bocek Village, Karangploso District, Malang Regency. The material used in this study was the marketing of cow milk Karangploso KUD Bocek Village Karangploso District, Malang Regency. The method used in this study is a survey method and direct interviews with members of the Karangploso KUD. Research variables include marketing costs, total marketing profits, and marketing margins. The results showed that marketing channels for cow's milk in Bocek Village, Karangploso Sub-District, Malang Regency were: Breeders $\rightarrow$ $\mathrm{KUD} \rightarrow$ IPS $\rightarrow$ and Consumers. Marketing costs Rp. 572.75 per litre, total marketing profit of Rp. 1,727.25 per litre and marketing margin of Rp. 2,300.00 per litre and marketing costs from KUD to consumers with total marketing costs of $\mathrm{Rp}$. 291.05 per litre, total marketing profit of $\mathrm{Rp}$. 2,808.96 per litre and marketing margin of Rp. 3,100. The conclusion of this study is that the marketing channel of cow's milk in Karangploso Village Cooperative in Bocek Village, Karangploso Subdistrict, Malang Regency is better. Suggestions that researchers can give to farmers in Bocek Village, Karangploso Subdistrict, Malang Regency, which must be further improved in raising dairy cows to get good quality milk.
\end{abstract}

Keywords: Cost, Margin, Marketing analysis, Farmers.

\section{PENDAHULUN}

Indonesia adalah negara agraris, dengan jumlah penduduk sebagian besar bermatapencaharian di bidang pertanian, sedangkan kegiatan pertanian itu sendiri meliputi pertanian tanaman pangan, perkebunan, perikanan dan peternakan. Pencapaian 
sasaran pembangunan sub sektor peternakan melibatkan peran serta pemerintah melalui berbagai program kegiatan untuk mencapai tujuan pembangunan peternakan. Sasaran pembangunan sub sektor peternakan yang ditetapkan dan diprioritaskan pada peningkatan populasi ternak, penyediaan susu, daging dan telur sebagai konsumsi dan meningkatkan kelembagaan informasi pasar untuk memperpendek jarak antara konsumen dan produsen. Usaha peternakan sapi perah merupakan salah satu usaha peternakan yang cukup berperan dalam perekonomian masyarakat pedesaan. Peternakan sapi perah merupakan salah satu bagian dari sub sektor peternakan yang diharapkan dapat menjadi tulang punggung dalam penyediaan protein hewani, karena salah satu tujuan dari pemerintah dalam mengembangkan sapi perah adalah untuk meningkatkan pendapatan peternak (Sudono dkk, 2003).

Menurut Nur dkk (2007), seiring dengan laju pertumbuhan penduduk, tuntutanpermintaan masyarakat terhadap kebutuhan susu sebagai sumber protein hewani cenderung mengalami peningkatan dari tahun ketahun, ini disebabkan meningkatnya kesadaran masyarakat akan pentingnya penyediaan gizi bagi terciptanya kesehatan manusia dan kondisi manusia yang semakin membaik. Susu segar adalah bahan pangan yang perisable (mudah rusak), karena mempunyai kadar air tinggi sekitar $87 \%-90 \%$ serta mempunyai nilai nutrisi yang lengkap sehingga baik untuk konsumsi manusia, hewan dan mikroorganisme, oleh karena itu perlu dilakukan pengolahan untuk mempertahankan kualitasnya. Teknologi pengolahan susu segar disamping menghambat kerusakan juga untuk penganekaragaman bahan pangan, karena dengan proses pengolahan kerusakan secara fisik, kimia, dan mikrobiologis akandapat dicegah dan sekaligus dapat menambah nilai ekonomis dari produk tersebut dan selanjutnya supaya dapat mempertahankan kualitasnya (Khotimah, 2009).

Menurut Mubyarto (2000), analisis pemasaran dianggap efisien apabiladianggap mampu menyampaikan hasil-hasil dari produsen kepada konsumen dengan biaya wajar serta mampu mengadakan pembagian yang adil dari keseluruhan harga yang dibayarkan konsumen Untuk mengetahui efisiensi pemasaran susu segar secara ekonomis adalah dengan melihat marjin dan bagian yang diterima peternak (farmer'share) pada setiap saluran pemasaran yang ada.

Menurut Winardi (2003) yang dimaksud dengan saluran distribusi adalah sebagai berikut: Saluran distribusi merupakan suatu kelompok perantara yang berhubungan erat satu sama lain dan yang menyalurkan produk-produk kepada pembeli. Sedangkan (Waryodi,2001) mengemukakan bahwa : Saluran distribusi adalah serangkaian 
organisasi yang saling tergantung dan terlibat dalam proses untuk menjadikan suatu barang atau jasa siap untuk digunakan atau dikonsumsi.

Distribusi pemasaran susupada dasarnya merupakan perantara yang dilalui antara produsen dan konsumen. Perantara tersebut dapat digolongkan kedalam dua golongan yaitu: Pedagang perantara dan agen perantara. Perbedaannya terletak pada aspek pemilikan serta proses negoisasi dalam pemindahan produk yang disalurkan tersebut (Iswan, 2002).

Marjin pemasaran adalah perbedaan antara harga yang dibayar oleh konsumen untuk produk tersebut dengan harga yang diterima oleh produsen untuk menghasilkannya. Marjin pemasaran ditentukan oleh sifat produk, selera dan preferensi konsumen. Memperhatikan jasa-jasa pemasaran (kualitas yang tinggi, pembungkusan dsb). Masalah penjualan yang berkaitan dengan pemasaran besarnya marjin pemasaran dapat bertambah karena, tidak efisiennya jasa-jasa pemasaran, prasarana pemasaran. Keuntungan para perantara dan pengolah yang tidak wajar (Zanto, 2004)

\section{METODE PENELITIAN}

Populasi penelitian adalah KUD di Desa Bocek Kecamatan Karangploso. Teknik penentuan jumlah sampel mengunakan teknik random sampling yaitu dari populasi yang mewakili seluruh karakteristik dari populasi. Sebuah populasi dengan kualitas besar dapat diambil sebagian dengan kualitas sempel yang mewakili sama persisi dengan kualitas dari populasi dengan kata representatif.

\section{Definisi Operasional}

\section{a. Pengertian Pemasaran}

Pemasaran dapat diartikan dengan menjual barang-barang tepat harga, tepat tempat dan dalam waktu yang tepat pula. Daerah jangkauan pemasaran ini untuk mencukupi kebutuhan masyarakat atau konsumen di dalam suatu wilayah terhadap barang yang dibutuhkan.

b. Biaya, Keuntungan, dan Margin Pemasaran

- Biaya Pemasaran

Besarnya biaya pemasaran susu segar dapat dihitung dengan menggunakan rumus sebagai berikut :

$\mathrm{Bp}=\mathrm{Bp} 1+\mathrm{Bp} 2+\mathrm{Bp} 3+\ldots \ldots . .+\mathrm{Bpn}$

Keterangan :

Bp Bp1, Bp2, Bp3,..,Bpn

$1,2,3, \ldots . \mathrm{n}$
: Biaya pemasaran susu segar

: Biaya pemasaran susu segar tiap-tiap lembaga pemasaran susu segar : Jumlah Lembaga 
- Keuntungan Pemasaran

Besarnya keuntungan pemasaran susu segar dapat dihitung denganmenggunakan rumus sebagai berikut :

$\mathrm{Kp}=\mathrm{Kp} 1+\mathrm{Kp} 2+\mathrm{Kp} 3+\ldots \ldots .+\mathrm{Kpn}$

Keterangan :

$\mathrm{Kp}$ $\mathrm{Kp} 1, \mathrm{Kp} 2, \mathrm{Kp} 3, \ldots . . . \mathrm{Kpn}$

: Keuntungan pemasaran susu segar

: Keuntungan pemasaran tiap-tiap lembaga pemasaran susu segar

- Margin pemasaran

Margin pemasaran adalah selisih harga ditingkat produsen dan tingkatkonsumen.

Secara sistematis margin pemasaran dirumuskan sebagai berikut:

$\mathrm{Mp}=\mathrm{Pr}-\mathrm{Pf}$

Keterangan :

$\mathrm{Mp} \quad$ : Margin pemasaran susu segar (Rp/liter)

$\operatorname{Pr} \quad$ : Harga susu segar ditingkat konsumen (Rp/liter)

Pf : Harga susu segar yang diterima produsen (Rp/liter)

Margin yang diperoleh pedagang perantara dari sejumlah biaya pemasaran yang dikeluarkan dan keuntungan yang diterima oleh pedagang perantara dirumuskan sebagai berikut:

$\mathrm{M} p=\mathrm{Bp}+\mathrm{Kp}$

Keterangan :

M p : Margin pemasaran susu segar ( $\mathrm{Rp} /$ liter)

$\mathrm{Bp} \quad$ : Biaya pemasaran susu segar $(\mathrm{Rp} / \mathrm{liter})$

$\mathrm{Kp} \quad$ : Keuntungan pemasaran susu segar (Rp/liter)

\section{- Efisiensi Pemasaran}

Efisiensi pemasaran dalam saluran pemasaran dapat dihitung dengan nilai persentase dari persentase margin pemasaran dari masing-masing saluran pemasaran digunakan rumus sebagai berikut :

a. Persentase Margin Pemasaran

$$
\mathrm{Mp}=(\underline{\mathrm{Pr}-\mathrm{Pf}}) \times 100 \%
$$

$\operatorname{Pr}$

Keterangan:

MP : Marjin pemasaran

PF : Harga ditingkat produsen (peternak)

PR : Harga ditingkat konsumen 


\section{Instrumen Penelitian}

Dalam penelitian ini instrumen digunakan untuk mengumpulkan data atau informasi dari respondent berdasarkan variabel penelitian. Instumen penelitian ini dengan teknik wawancara cara langsung dengan anggota KUD Karangploso.

\section{Pengumpulan Data}

Adapun teknik pengumpulan data melalui :

a) Data primer di ambil dari data yang diperoleh dari responden melalui angket/kuesioner, kelompok fokus, dan panel atau juga data hasil wawancara peneliti dengan nara sumber.

b) Data sekunder di ambil dari data penunjang atau sumber tidak langsung seperti melalui media internet, majalah.

\section{Analisis Data}

Data yang di peroleh akan di analisis secara deskriptif. Analisis deskriptif adalah suatu cara menggambarkan persoalan yang berdasarkan data yang dimiliki yakni dengan cara menata data tersebut sedemikian rupa sehingga dengan mudah dapat dipahami tentang karakteristik data, dijelaskan dan berguna untuk keperluan selanjutnya.

\section{HASIL DAN PEMBAHASAN}

Proses mengalirnya barang dari peternak ke konsumen memerlukan biaya, denganadanya biaya pemasaran maka suatu produk akan lebih tinggi harganya. Semakin panjang rantai pemasaran maka biaya yang dikeluarkan dalam pemasaran akan semakin meningkat. Untuk mengetahui besarnya biaya, keuntungan dan marjin pemasaran susu segar pada saluran pemasaran di Kecamatan Karangploso Kabupaten Malang dapat dilihat pada Tabel 1.

Berdasarkan Tabel diatas pada saluran pemasaran harga yang dibayar oleh KUD Karangploso ke responden peternak pada waktu penelitian harga terendah adalah $\mathrm{Rp}$ 4.400 per liter dan harga tertinggi Rp 4.700 per liter sehingga rata-rata harga susu segar sebesar Rp 4.700 per liter, harga yang dibayarkan KUD tergantung kualitas susu segar, dengan pembayaran oleh KUD Karangploso ke peternak secara bertahap dilakukan sebulan sebanyak tiga kali yaitu setiap tanggal 2, 12 dan 22. Selama proses pemasaran, 
peternak mengeluarkan biaya transportasi dan biaya penyusutan. Biaya transportasi adalah biaya yang dikeluarkan peternak untuk menyetorkansusunya sampai ke TPS. Alat transportasi yang dipakai biasanya sepeda motor.

Tabel 1 . Biaya, Marjin, dan Keuntungan Saluran Pemasaran Susu Segar ke IPS di Kecamatan Karangploso Kabupaten Malang.

\begin{tabular}{lrr}
\hline Uraian & & Rp/liter \\
Koperasi Unit Desa (KUD) & & \\
\hline $\begin{array}{l}\text { a.Harga Beli Susu Segar dari peternak } \\
\text { b. Biaya Pemasaran }\end{array}$ & $\mathrm{Rp}$ & $4.700,00$ \\
1) Biaya Proses & $\mathrm{Rp}$ & 93,89 \\
$\quad$ Penampungan(Pendingin) & & \\
$\quad$ Saringan & $\mathrm{Rp}$ & 9,39 \\
$\quad$ Jumlah biaya & $\mathrm{Rp}$ & 103,28 \\
2) Biaya Transportasi & $\mathrm{Rp}$ & 281,69 \\
3) Biaya Sanitasi & & \\
$\quad$ Penyaringan Susu & $\mathrm{Rp}$ & 93,89 \\
4) Biaya Operasional & & \\
$\quad$ Biaya tenagga kerja & $\mathrm{Rp}$ & 93,89 \\
Jumlah Biaya & $\mathrm{Rp}$ & 572,75 \\
c. Keuntungan Pemasaran & $\mathrm{Rp}$ & $1.727,25$ \\
d. Marjin Pemasaran & $\mathrm{Rp}$ & $2.300,00$ \\
e. Harga Jual & $\mathrm{Rp}$ & $7.000,00$ \\
Total Marjin Pemasaran & $\mathbf{R p}$ & $\mathbf{2 . 3 0 0 , 0 0}$ \\
a. Total Biaya Pemasaran & $\mathrm{Rp}$ & 572,75 \\
b. Total Keuntungan Pemasaran & $\mathrm{RP}$ & $1.727,25$ \\
\hline Sumber Data Prim dian, 2016 & &
\end{tabular}

Sumber: Data Primer diolah, 2016

Biaya pemasaran yang dikeluarkan oleh KUD meliputi biaya proses, biaya transportasi, biaya sanitasi, dan biaya operasional. Keuntungan pemasaran yang diperoleh KUD Karangploso adalah sebesar Rp 1.727,24 per liter. Sehingga diperoleh marjin pemasaran KUD Karangploso sebesar Rp 2.300per liter. Biaya paling tinggi adalah biaya proses. Hal ini dikarenakan produk susu segar tidak tahan lama dan mudah rusak sehingga KUD Karangploso harus segera menampung susu yang dari peternak yang langsung dimasukkan ke cooling unit untuk proses pendinginan sampai suhu mencapai 2$4{ }^{\circ} \mathrm{C}$ ini dilakukan dengan tujuan untuk menghambat pertumbuhan bakteridan mencapai standar kualitas yang dikehendaki IPS ,harga beli IPS Rp. 7.800,-/litersesuai dengan ratarata standar kualitas TS dan protein. Selain ke IPS, KUD Karangploso juga menjual langsung kepada home industry, pedagang pengecer, dan konsumen rumah tangga dengan harga Rp. 7.000,- agar KUD tidak menanggung biaya resiko yang tinggi. Biaya terendah adalah biaya sanitasi, biaya ini dikeluarkan oleh KUD untuk membayar kebersihan alat yang ada di KUD Karangploso maupun di TPS seperti saringan, milk can, dan peralatan dalan pendinginan susu segar di KUD Karangploso total biaya pemasaran di peroleh dari penjumlahan biaya peternak dan biaya KUD Karangploso. Dari penjumlahan tersebut 


\section{Jurnal Sains Peternakan}

Vol 6, No 1, Juni 2018, pp: 1-8

ISSN 2579-4450

diperoleh total biaya pemasaran sebesar Rp 572,76 per liter. Keuntungan pemasaran juga diperoleh dari keuntungan lembaga pemasaran yaitu sebesar Rp 1.727,24 per liter dan total marjin pemasaran adalah Rp 2.300,00 per liter (Setyowati dan Arianto, 2008)

Tabel 2. Biaya, Marjin, dan Keuntungan Saluran Pemasaran Susu Sapi Ke konsumen di Kecamatan Karangploso Kabupaten Malang.

\begin{tabular}{ll}
\hline Uraian & $\mathrm{Rp} /$ liter \\
\hline a.
\end{tabular}

a. Biaya Pemasaran

1) Biaya Proses Penampungan (Pendingin)

Rp $\quad 93,89$

Saringan

Rp $\quad 9,38$

2) Biaya Sanitasi Penyaringan Susu

Rp 93,89

3) Biaya Operasional Biaya tenagga kerja

Rp 93,89

Total Biaya

Rp 291,05

b. Keuntungan Pemasaran

Rp 2.808,95

c. Marjin Pemasaran

Rp 3.100,00

d. Harga Jual

Rp 7.800,00

Total Marjin Pemasaran

Rp 3.100,00

e. Total Biaya

Rp 291,05

f. Total Keuntungan

RP $\mathbf{2 . 8 0 8 , 9 5}$

Sumber: Data Primer diolah, 2016

Biaya pemasaran yang dikeluarkan oleh KUD meliputi biaya proses, biaya sanitasi, dan biaya operasional. Keuntungan pemasaran yang diperoleh KUD Karangploso adalah sebesar Rp 2.808,94per liter. Sehingga diperoleh marjin pemasaran KUD Karangploso sebesar Rp 3.100 per liter

Tabel 3. Keuntungan KUD Karangploso Menjual Susu Sapi /hari

\begin{tabular}{|c|c|c|c|c|}
\hline No & Menjual & Jumlah Susu/liter & Keuntungan/liter & keuntungan \\
\hline 1 & Konsumen(15\%) & 798,75 & Rp $1.727,25$ & Rp 1.379.640,00 \\
\hline 2 & IPS $(85 \%)$ & Rp 4.526,25 & Rp 2.808,95 & Rp12.714.009,00 \\
\hline & Total & & & Rp 4.093.649,00 \\
\hline
\end{tabular}

Jadi hasil dari penjual susu sapih di KUD Karangploso Desa Bocek Kecamatan Karangploso Kabupaten Malang mendapatkan keuntungan menjual susu sapi ke konsumen (15\%) dengan Rp 1.379.640 dan IPS (85\%) dengan Rp 12.714.009 sehingga total keuntungan yang didapat yaitu Rp 14.093,60

\section{KESIMPULAN}

1. Biaya total marjin pemasaran ke konsumen Rp 2.300 per liter sedangkan keuntungan pemasaran mendapatkan total Rp 1.727,25per liter

2. Biaya total marjin pemasaran ke IPS Rp 3.100 per liter sedangkan keuntungan pemasaran mendapatkan total Rp 2.808,96 
3. Total keuntungan menjual susu sapi kekonsumen Rp 1.379.640 (15\%) dan IPS Rp dengan Rp 12.713 .964 (85\%) sehingga total keuntungan yang didapat yaitu Rp 13.796 .527

\section{UCAPAN TERIMA KASIH}

Ucapan terima kasih disampaikan kepada semua pihak terutama KUD Karangploso Desa Bocek Kecamatan Karangploso Kabupaten Malang yang telah banyak membantu sejak persiapan hingga terselenggaranya penelitian ini dengan baik.

\section{DAFTAR PUSTAKA}

Iswan. 2002. Analisis Pemasaran Keripik Tempe di Kecamatan Sambung macan Kabupaten Sragen. Skripsi S1 Program Studi Sosial Ekonomi Pertanian/Agrobisnis Fakultas Pertanian Universitas Sebelas Maret Surakarta. Tidak Dipublikasikan.

Khotimah.2009 Pembuatan Susu Bubuk Dengan Foam-Mat Drying : Kajian Pengaruh Bahan Penstabil Terhadap Kualitas Susu Bubuk. http:// peperonity.com. Diakses hari 10 Januari 2016.

Mubyarto. 2000. Pengantar Ekonomi Pertanian. LP3ES. Jakarta

Nur, R., Muh. Amir. S., dan Kartika. E. 2007. Analisis Margin Pemasaran Telur Itik di Kelurahan Borongloe Kecamatan Bontomarannu Kabupaten Gowa. Jurnal Agrisistem. Vol. 3. No 1. Juni 2007.

Setyowati dan Arianto, 2008. Jurnal Ilmu-ilmu Pertanian, Volume 4, Nomor 2.

Sudono, A., Fina. R., dan Budi S.S. 2003. Beternak Sapi Perah Secara Intensif. PT Agromedia Pustaka. Jakarta.

Waryodi. 2001. Teknis Saluran Pemasaran. PT Agromedia, Pustaka

Winardi. 2003. Manajemen Pemasaran. Liberty, Yogyakarta.

Zanto. 2004. Prinsif Analisi Pemasaran. Pusat Penelitian dan Pengembangan Peternakan Bogor. 